\title{
Recent Indonesian Economic Development and the Urgent Need to Remove Key Growth Obstacles*
}

\section{Arianto A. Patunru \\ Arndt-Corden Department of Economics \\ Australian National University and Institute for Economic and Social Research \\ University of Indonesia \\ (LPEM-FEUI) \\ Jalan Salemba Raya 4 Jakarta I0430, Indonesia patunru@|pem-feui.org}

\section{Tarsidin}

Institute for Economic and Social Research

University of Indonesia (LPEM-FEUI)

Jalan Salemba Raya 4 Jakarta 10430, Indonesia tarsidin@|pem-feui.org

\begin{abstract}
Turbulence has been the hallmark of the course of Indonesian economic growth. Indonesia was dubbed a "chronic drop-out" in economic performance in 1968, but it then immediately embarked on a growth spurt. Just as accolades to Indonesia's economic pragmatism and economic orthodoxy were reaching a new height, Indonesia's economy shattered during the Asian financial crisis of 1997-99. Indonesia has once again risen phoenix-like from that disaster, and the bounce back has been resilient in the face of the 2008 global financial crisis. Despite the commendable progress, however, its growth seems to be hindered. Indonesia must now tackle the two most important constraints to its continued high growth: logistics and infrastructure.
\end{abstract}

\section{Background}

More than four decades ago, Benjamin Higgins wrote an assessment on Indonesia as one of the case studies in his famous book, Economics Development (Higgins 1968). He titled the chapter "Indonesia: The Chronic Drop-out" and started with a rather dark picture: "Indonesia must surely be accounted the number one economic failure among the major underdeveloped countries" (Higgins 1968, 678). Higgins laid out a long list of depressing facts: per capita income in 1966 was less than that in 1938, budget deficits reached half of government expenditures, hyperinflation

* The authors thank Anwar Nasution, James Wen, and all the participants of the Asian Economic Panel meeting at Columbia University on 24-25 March 2011, and acknowledge the feedback from seminar participants at the Harvard Kennedy School on 28 March 2011. We also thank Thee Kian Wie for useful references and discussion. 
was one of the world's worst cases, and so forth. He concluded that the reason for Indonesia's failure since the colonial period all the way until the 1960s was the absence of a needed combination of "big push," economic leadership, and a political framework that encourages entrepreneurship.

Another influential book came out almost 30 years later, written by Hal Hill: The Indonesian Economy Since 1966 (Hill 1996). In stark contrast with Higgins' gloomy account, Hill's was a story of success. According to Hill, "The Indonesia of the mid 1990s is almost unrecognizable in a comparison with that of the mid 1960s" (Hill 1996, 3). Hill recorded high growth, rapid structural and technological change, and dramatically reduced inflation. Furthermore, indicators of human welfare had improved (e.g., poverty incidence fell sharply and education statistics showed promising trends). He asserted that, despite some characterizing it as a "miracle" (e.g., World Bank 1993), the recipe to Indonesia's success is no great secret: It is pragmatism and orthodoxy. He credited the success to the government, which provided a stable economic and political environment, respected property rights, re-entered the international community, reduced distortions in prices, and provided public goods.

Almost immediately after the publication of Hill's book in 1996, however, the successful country plunged into the catastrophe now known as the 1997-99 Asian financial crisis (AFC). ${ }^{1}$ The AFC practically collapsed Indonesia's economy. Today, more than a decade after that catastrophic crisis, Indonesia has stood up again. It has even weathered the 2008 global financial crisis (GFC) quite impressively. We argue in this paper, however, that Indonesia still faces many constraints, and these constraints have been preventing the country from reaching higher economic growth. Production networks have been expanding at a vigorous pace throughout East Asia and hence enriching the region tremendously in the process. The trouble is that Indonesia is lagging behind in its integration into these production networks. Unless Indonesia removes the constraints that hold its competitiveness back, continued high growth will be threatened.

\section{Macroeconomic management}

\section{I Economic growth}

During the period of 1986-95 Indonesia experienced impressive high economic growth (i.e., around 6.8 percent on average), better than India, Lao People's Democratic Republic (Lao PDR), the Philippines, and Vietnam. The AFC essentially exploded Indonesia's economy, politics, and society; and the socio-political landscape changed drastically_-for example, becoming more democratic and transparent. In

1 A second edition was quickly released in 2000 (Hill 2000). 
the period of 2000-10, the average economic growth was 5.2 percent, slightly better than Malaysia (5.0 percent), the Philippines (4.6 percent), and Thailand (4.4 percent). Indonesia is one of the few countries with good economic performance in the aftermath of the recent GFC. It is projected that in 2011 Indonesia's economic growth will record an impressive growth of around 6.2 percent (IMF 2010).

Indonesia's GDP breakdown by expenditure is depicted in Table 1. By far, private consumption expenditure is still the biggest contributor (measured as share to GDP). The gross fixed capital formation that had been on the rise during 1993-97 recorded a 28.5 percent share in 1997 , but then plunged to only 17.8 percent amidst the crisis. Since then it gradually recovered, and by 2010 it contributed 24 percent to GDP, despite a small hiccup in 2009 due to the GFC. In fact, the growth of investment spending has become the major driver of GDP growth in 2010, with a growth rate consistently faster than overall growth (McLeod 2011). Another important improvement is that of trade. In 1993 export contributed only 37.6 percent to GDP and import contributed 29.1 percent. In 2010 both export and import rose significantly, with contributions of 46.4 percent and 36 percent to GDP, respectively.

\subsection{Monetary policy and banking}

Throughout the last decade, Bank Indonesia has helped to keep the Indonesian macroeconomy fairly stable, characterized by reasonably low inflation rates and relatively stable rupiah exchange rates. Bank Indonesia seems to have achieved this rather inefficiently, however. In the period 2000-08, for example, the SBI interest rate (SBIs are the short-term money certificates issued by Bank Indonesia) was constantly higher than the time deposit rate of commercial banks, as shown in Figure 1.

It is uncommon that Bank Indonesia's instrument, which is less risky, earned a higher return than that of commercial banks. An SBI rate that is higher induces the commercial banks to put their money in SBI rather than lending it out to debtors. The loan-to-deposit ratio of commercial banks was extremely low-at around 30 percent to 50 percent in the period 2000-04 (by now, however, it has increased to around 77 percent). The high rate of SBI also induces foreign capital inflow that brings the risk of a "hot money" problem. This situation was the case for 8 years, before it broke in January 2009 after the GFC hit Indonesia. Therefore although the policy to keep the SBI rate higher than the time deposit rate has been effective in absorbing money from circulation, this policy should really be implemented only in a crisis situation, rather than during normal conditions.

Another much-discussed issue regarding monetary and banking policy is the relatively wide spread between the bank lending rate and the deposit rate. For a long time now, it has remained at around 5 percent to 6 percent. Businesses have been 


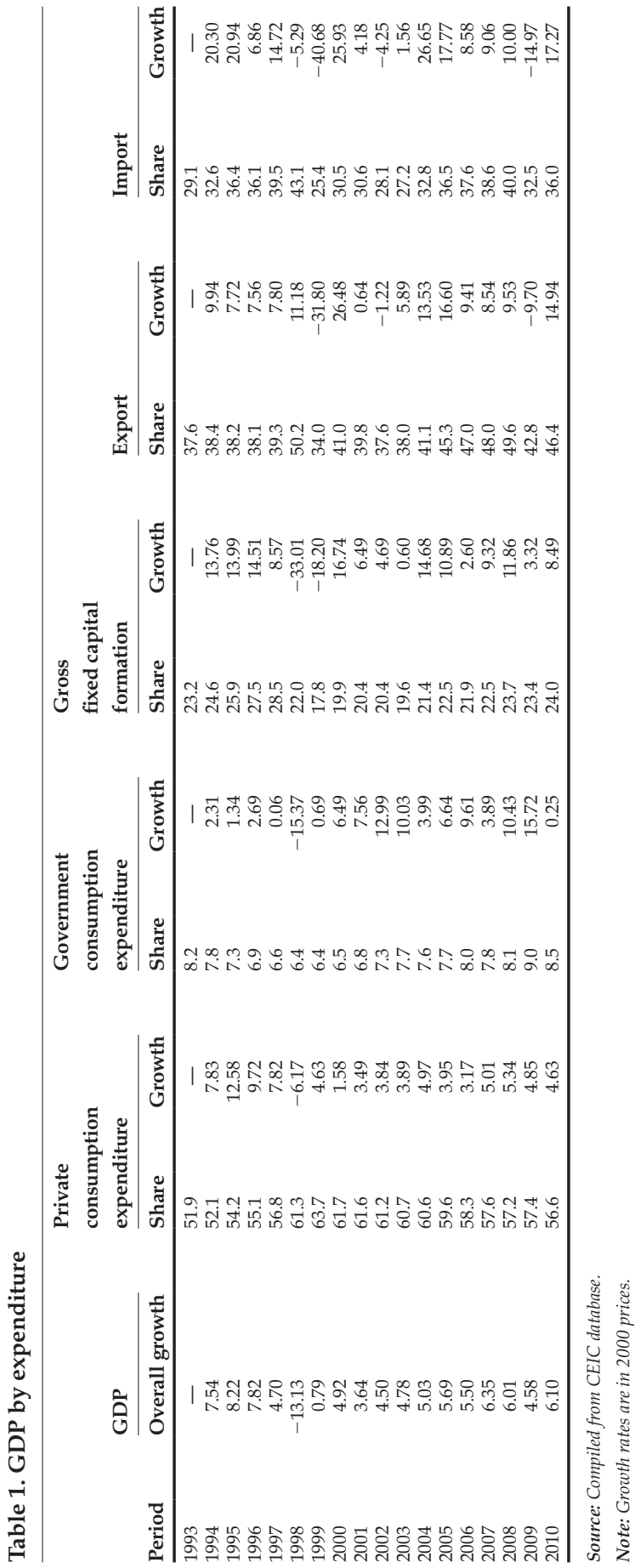




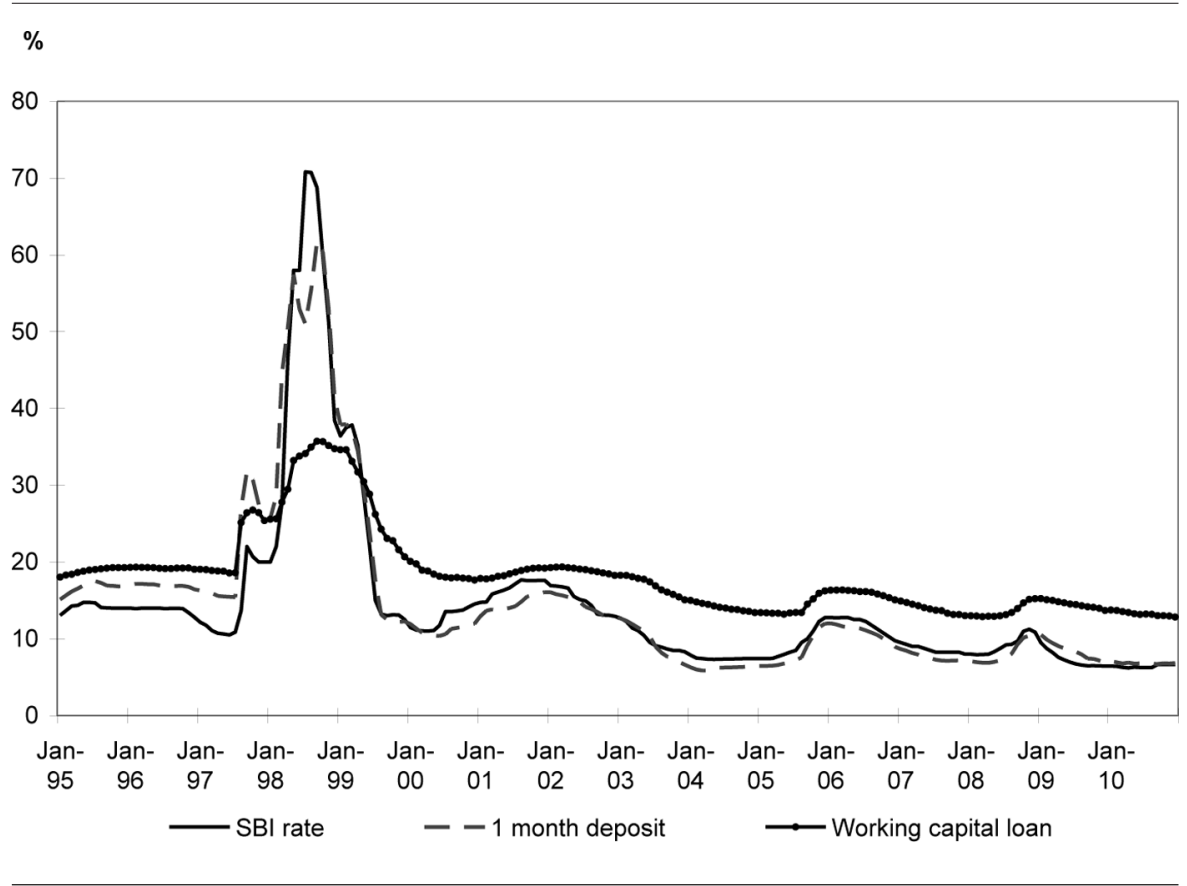

Source: Compiled from CEIC database.

complaining about the high lending rates. The rather oligopolistic Indonesian banking structure (there are 15 commercial banks with around 80 percent of the market share) might have exacerbated the problem.

\subsection{Fiscal policy and government financing}

The Indonesian government has succeeded in reducing its dependence on debt from 89 percent of GDP in 2000 to around 30 percent currently-a low ratio by international standards (Ashcroft and Cavanough 2008). In 1998 the Indonesian government started issuing government bonds as a new financing instrument. These bonds (called Surat Berharga Negara) were first used to recapitalize insolvent banks taken over by the government. At that time they were denominated almost exclusively in rupiah. Since 2004, the government has also issued foreign currency denominated securities.

At the end of 2009 there were Rp 724.90 trillion worth of tradable bonds and Rp 254.56 trillion worth of non-tradable bonds. There were Rp 581.75 trillion of domestic bonds and Rp 143.15 trillion of foreign bonds (USD 14.85 billion and JPY 35 billion) that were tradable. By the end of 2009 government debt had 
Table 2. Subsidies in the national budget

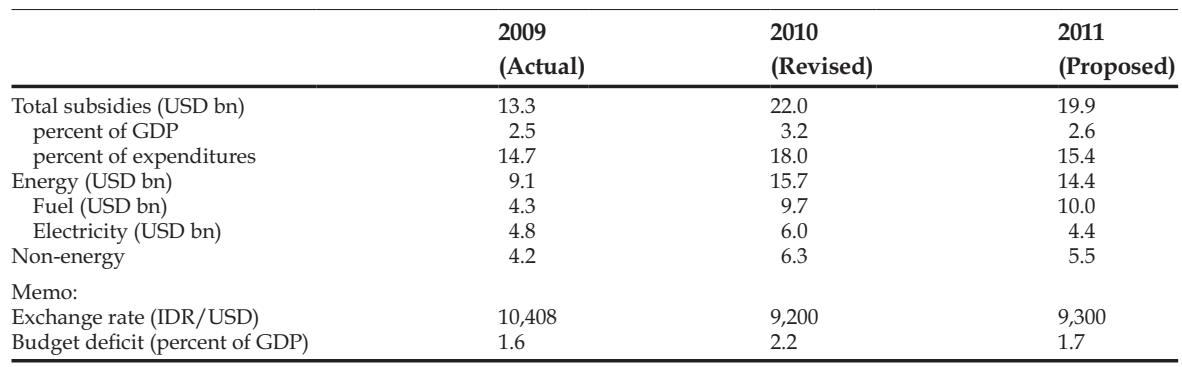

Source: Government of Indonesia (GOI) (various years), Patunru (2010).

amounted to USD 170.7 billion-USD 88.3 billion of which was denominated in rupiah and the rest in foreign currencies.

The government seems to have set the bond prices too low, however. For some period the difference between yields of government bonds and the SBI rate was remarkably wide, such as in the period of October 2008-June 2009. This wide a gap raises a question of efficiency; both SBI and government bonds are risk-free and hence their return should not be too far apart. Now, however, the government has been better in establishing the bond price.

Of particular concern in fiscal policy is the consistently large portion allocated for subsidy (Patunru 2010). Obviously subsidies are often needed for development purposes, especially to ensure the sufficient provision of public goods. As shown in Table 2, however, the subsidy allocation is high (i.e., between 2.5 to 3 percent of GDP). This is higher than the budget deficit of around 1.5-2.2 percent of GDP. Energy subsidy takes up a huge portion of the total subsidy (with fuel subsidy dominating the total energy subsidy). The subsidized non-energy items include food, fertilizer, and seeds. It is obvious that this "subsidy regime" in the budget is not sustainable, as a big portion of the budget is used for non-productive uses. Infrastructure, for example, is the sector mostly in need of a big spending allocation. Unfortunately, only about 8 percent of total government spending goes to infrastructure development, which is far below that allocated for energy subsidy (13-20 percent) (Thee and Negara 2010).

\subsection{Foreign trade and capital flow}

Indonesian export and import performance has risen significantly in recent years. Table 3 shows that there has been a shift in Indonesia's exports in terms of commodities. In 1993 and prior, Indonesia relied on the export of petroleum and gasaround 26.48 percent of total export. In 2010 the contribution of this commodity di- 
Table 3. Major exports (percent of total)

\begin{tabular}{|c|c|c|c|c|c|}
\hline SITC & Commodity & 1993 & 2000 & 2005 & 2009 \\
\hline 03 & Fish, crustacean and mollusks, and preparations thereof & 3.86 & 2.56 & 2.10 & 1.93 \\
\hline 07 & Coffee, tea, cocoa, spices, and manufactures thereof & 2.33 & 1.79 & 1.73 & 2.37 \\
\hline 23 & Crude rubber (including synthetic and reclaimed) & 2.66 & 1.47 & 3.05 & 2.82 \\
\hline 28 & Metalliferous ores and metal scrap & 2.44 & 3.18 & 5.30 & 5.61 \\
\hline 32 & Coal, coke, and briquettes & 1.75 & 2.09 & 5.08 & 11.87 \\
\hline 33 & Petroleum, petroleum products, and related materials & 15.47 & 12.50 & 11.93 & 8.75 \\
\hline 34 & Gas, natural and manufactured & 11.01 & 10.67 & 10.69 & 7.67 \\
\hline 42 & Fixed vegetable oils and fats & 1.92 & 2.66 & 5.56 & 10.18 \\
\hline 51 & Organic chemicals & 0.66 & 1.84 & 1.91 & 1.58 \\
\hline 63 & Cork and wood, cork manufactures & 13.94 & 5.20 & 3.12 & 1.55 \\
\hline 64 & Paper, paperboard, and articles of pulp, of paper/of paperboard & 1.34 & 3.71 & 2.72 & 2.92 \\
\hline 65 & Textile yarn, fabrics, made-up articles, nes, and related products & 7.22 & 5.66 & 4.04 & 2.76 \\
\hline 68 & Non-ferrous metals & 0.80 & 1.58 & 3.03 & 3.42 \\
\hline 75 & Office machines and automatic data processing equipment & 0.43 & 4.90 & 3.43 & 1.37 \\
\hline 76 & Telecommunications, sound recording and reproducing equipment & 2.62 & 5.64 & 3.59 & 3.35 \\
\hline 77 & Electric machinery, apparatus and appliances nes, and parts nes & 1.19 & 4.08 & 4.72 & 3.47 \\
\hline 82 & Furniture and parts thereof & 1.84 & 2.46 & 2.17 & 1.43 \\
\hline 84 & Articles of apparel and clothing accessories & 9.67 & 7.74 & 6.03 & 5.14 \\
\hline 85 & Footwear & 4.42 & 2.59 & 1.57 & 1.45 \\
\hline 89 & Miscellaneous manufactured articles, nes & 2.15 & 2.25 & 1.68 & 1.60 \\
\hline
\end{tabular}

Source: Compiled from UN-COMTRADE database.

Note: nes $=$ not elsewhere specified.

minished to 17.78 percent. The remaining 82.22 percent exports consist of agriculture goods (3.17 percent), industrial goods (62.14 percent), and mining and others (16.91 percent). Shifts in sub-commodities are also apparent. In 1993 commodities like cork and wood, cork manufactures; textile yarn, fabrics, made-up articles, and related products; and articles of apparel and clothing accessories, contributed significantly to the total export with more than 30 percent share. Their share in 2009 dropped to only 9.45 percent, however. On the other hand, commodities such as coal, coke and briquettes, and fixed vegetables, oils, and fats have risen significantly.

Furthermore, as shown in Table 4, import of petroleum, petroleum products, and related materials increased significantly, from 7.66 percent in 1993 to 19.27 percent in 2009. The current estimate for the contribution of this commodity in 2010 is around 20.18 percent. Table 4 also shows that the import of "other transport equipment" has also more than doubled from 1993 to 2009. But import contribution of machinery that is specialized for particular industries has dropped to 4.36 percent. This could mean that domestic industries have been able to supply the machinery. In $2010 \mathrm{im}$ port of consumer goods was around 7.37 percent, raw material/supporting material 72.78 percent, and capital goods around 19.85 percent

\section{Structural change}

\section{I Sectoral transformation}

Table 5 reports sectoral growth performance. The agriculture sector was 16.8 percent of GDP in 1993 and 13.8 percent of GDP in 2007. Agriculture employs more than 
Table 4. Major imports (percent of total)

\begin{tabular}{|c|c|c|c|c|c|}
\hline SITC & Commodity & 1993 & 2000 & 2005 & 2009 \\
\hline 4 & Cereals and cereal preparations & 1.93 & 3.28 & 1.86 & 1.91 \\
\hline 8 & Feeding stuff for animals (not including un-milled cereals) & 1.18 & 1.45 & 1.43 & 1.73 \\
\hline 25 & Pulp and waste paper & 1.69 & 3.18 & 1.36 & 0.98 \\
\hline 26 & Textile fibers (not wool tops) and their wastes (not in yarn) & 2.82 & 3.00 & 1.39 & 1.22 \\
\hline 33 & Petroleum, petroleum products, and related materials & 7.66 & 18.39 & 30.60 & 19.27 \\
\hline 51 & Organic chemicals & 4.26 & 7.39 & 5.48 & 3.89 \\
\hline 58 & Artificial resins and plastic materials, and cellulose esters etc. & 3.51 & 3.26 & 2.72 & 2.75 \\
\hline 59 & Chemical materials and products, nes & 1.84 & 1.88 & 1.42 & 1.41 \\
\hline 65 & Textile yarn, fabrics, made-up articles, nes, and related products & 3.99 & 3.75 & 1.31 & 2.89 \\
\hline 67 & Iron and steel & 5.58 & 4.86 & 6.59 & 5.24 \\
\hline 68 & Non-ferrous metals & 1.83 & 1.85 & 1.52 & 1.67 \\
\hline 69 & Manufactures of metals, nes & 2.25 & 1.70 & 1.63 & 2.07 \\
\hline 71 & Power generating machinery and equipment & 5.71 & 2.81 & 2.96 & 3.58 \\
\hline 72 & Machinery specialized for particular industries & 10.72 & 5.47 & 4.88 & 4.36 \\
\hline 74 & General industrial machinery and equipment nes \& parts of nes & 7.66 & 5.28 & 5.05 & 5.49 \\
\hline 75 & Office machines and automatic data processing equipment & 0.71 & 0.64 & 0.89 & 2.31 \\
\hline 76 & Telecommunications, sound recording and reproducing equipment & 3.53 & 1.20 & 2.43 & 4.81 \\
\hline 77 & Electric machinery, apparatus and appliances nes, and parts nes & 6.04 & 2.78 & 2.83 & 5.89 \\
\hline 78 & Road vehicles & 4.67 & 5.53 & 5.26 & 3.96 \\
\hline 79 & Other transport equipment & 2.75 & 3.16 & 1.43 & 6.19 \\
\hline
\end{tabular}

Source: Compiled from UN-COMTRADE database.

Note: nes $=$ not elsewhere specified.

40 percent of the labor force and contains roughly 65 percent of the poor people. Agricultural output grew only around 3 percent annually. The composition of growth in Table 5 raises concern because recent growth seems to be supported mostly by sectors (electricity, transport, and telecommunications) that absorb only a few workers.

There are still around 40 million people working in the agriculture sector in Indonesia. Many of the farmers are working peasants with no or insufficient land, and their real wages are almost constant while real wages in other sectors are increasing. Certainly the best support and protection for farmers is through assistance on improving their skill and productivity. Such programs were conducted two or three decades ago but apparently now the government prefers a price subsidy mechanism (mostly price support for crops and fertilizers, along with occasional trade protection). Although such price subsidies might be justified in the short term, it will not be sufficient to improve well-being in the long run.

\subsection{Industrial transformation}

Indonesia's industrial transformation took place most notably in 1993-2009.

Table 6 reports that there was a movement away from labor-intensive and resourceintensive industries to capital-intensive industries in the composition of Indonesia's major manufactured exports. The share of resource-intensive industries dropped from 27.9 percent in 1993 to 5.8 percent in 2009, and the share of labor-intensive industries dropped from 59.7 percent to 55.3 percent. Consequently, capital-intensive 


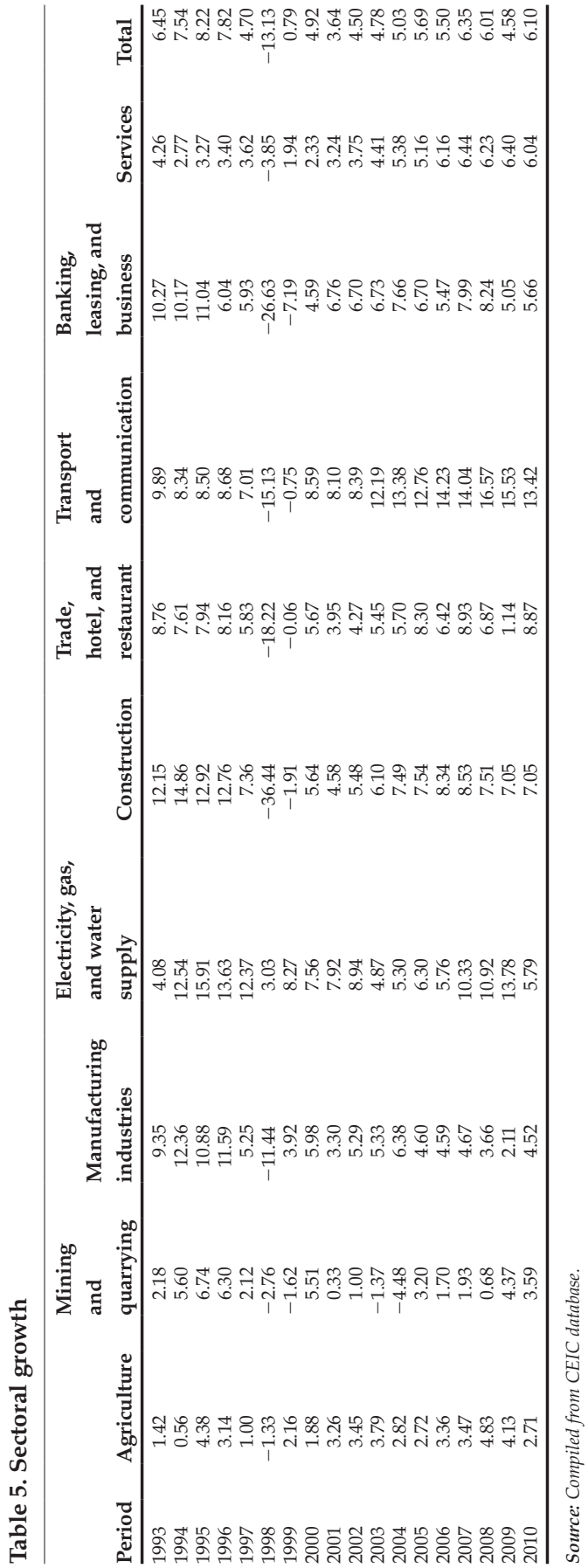


Table 6. Major manufactured exports (percent of total)

\begin{tabular}{|c|c|c|c|c|}
\hline Classification & 1993 & 2000 & 2005 & 2009 \\
\hline Resource-intensive & 27.92 & 11.01 & 8.52 & 5.81 \\
\hline Labor-intensive & 59.74 & 58.44 & 56.79 & 55.29 \\
\hline Capital-intensive & 12.33 & 30.56 & 34.69 & 38.90 \\
\hline
\end{tabular}

Source: Authors' calculations based on data compiled from UN-COMTRADE.

Note: Continuing on Hill (1996), the following classifications are used: Resource-intensive are SITC items 61, 63, 66 (excluding 664-6), and 671.

Labor-intensive are SITC items 54, 55, 65, 664-6, 695-7, 749, 76-7, 793, 81-5, and 89.

Capital-intensive are SITC items 5 (excluding 54 and 55), 62, 64, 67 (excluding 671), 69 (excluding 695-7), 7 (excluding 76-8), and 86-8. In the interest of longer time-span, we use SITC Rev 2.

industries rose from 12.3 percent in 1993 to 38.9 percent in 2009. There is therefore the justified concern about job creation in the industrial sector.

The domestic manufacturing industry is currently facing a slow down, it had gone from 23.5 percent of GDP in 1993 to peak at 28.4 percent in 2004 and then fell steadily to 27.4 percent. The manufacturing industry had grown 9-12 percent during 1993-96 but, post-AFC, grew only 2.11 percent to 6.38 percent in $2000-10$. In response to the diminishing performance of the manufacturing industry (or "deindustrialization" as some observers dub it), the government has launched a series of policies to boost the development of the industry through industrial revitalization programs, improving the investment climate, and accelerating infrastructure development programs. The full impact of all this is not yet clear.

\subsection{Decentralization}

Another aspect of Indonesia's structural change is regional decentralization, where some of the development tasks are delegated to regional authorities. This "bigbang" decentralization began in 2001. In practice, the country devolved administrative, fiscal, and political control to over 480 district-level governments, while keeping control over defense, national security, foreign policy, monetary policy, finance, development planning, justice, and the police in the hands of the central government.

Although the objective is well justified-namely, to let people in local regions take charge of their own developmental needs-some unintended consequences have occurred. For example, coordination between the central government and regional government becomes less manageable. Some regional governments even set their own objective function without coordinating it with the central government's agenda. Many regional governments also issue their own regulation or by-laws that contradict the central government level and hence exacerbate uncertainties that in 
Table 7. Poverty and inequality: Indonesia in comparison

\begin{tabular}{llll}
\hline Country & $\begin{array}{l}\text { Percent of population below } \\
\text { USD 2 (PPP)/day }\end{array}$ & $\begin{array}{l}\text { Income ratio of highest } \\
\text { 20 percent to lowest 20 percent }\end{array}$ & Gini coefficient \\
\hline China & $35.7(2005)$ & $8.3(2005)$ & $0.415(2005)$ \\
India & $75.6(2005)$ & $5.6(2005)$ & $0.368(2005)$ \\
Indonesia & $54.6(2005)$ & $6.2(2007)$ & $0.376(2007)$ \\
Lao PDR & $76.9(2002)$ & $4.9(2002)$ & $0.326(2002)$ \\
Cambodia & $57.8(2007)$ & $8.1(2007)$ & $0.442(2007)$ \\
Malaysia & $7.8(2004)$ & $7.0(2004)$ & $0.379(2004)$ \\
Philippines & $45.0(2006)$ & $9.0(2006)$ & $0.440(2006)$ \\
Thailand & $11.5(2004)$ & $8.1(2004)$ & $0.425(2004)$ \\
Vietnam & $48.4(2006)$ & $6.4(2006)$ & $0.378(2006)$ \\
\hline
\end{tabular}

Source: $A D B$ (2010).

Note: $P P P=$ purchasing power parity.

turn degrade the investment climate. Investors have complained that they must comply with too many regulations, which translates into higher transaction costs. Our opinion is that the most important step in minimizing this negative consequence is to improve the skills of local governments in drafting local regulations, and to implement stronger monitoring and strict enforcement (Brodjonegoro 2004).

\section{Social development}

Currently, more than half of Indonesia's population is still poor, measured with the USD 2 purchasing power parity/day poverty line. It is better than India, Lao PDR, and Cambodia, but worse than China, the Philippines, and Vietnam (Table 7). The two measures of income inequality show Indonesia is comparable to Vietnam, ${ }^{2}$ but more inequitable than India.

Poverty in Indonesia has three salient features (World Bank 2006). First, there is a large number of Indonesians vulnerable to poverty. That is, poor people just above the poverty line are sensitive to the change in the line. As a result, mobility of the near-poor to join the poor (and vice versa) is high. Using panel data from the periods 2002-04 and 2005-07, a study by Suselo and Tarsidin (2008a) revealed that some portion of poverty is not sufficiently acknowledged. They decomposed the poverty into "chronic" (i.e., poor for 3 consecutive years; due to limitation of panel data period, population was only identified for 3 years) and "transitory" (i.e., poor for 1 year or poor for 2 years, either consecutive or not). They found that 24-25 percent of the people are transiently poor and 4-5 percent are chronically poor. In total, the Head Count Ratio (HCR) for poverty for the 3 years covered was 29 percent. The

2 Comparison of Gini coefficients across countries should be taken with caution as the survey conducted in each country to generate the coefficient may be different in methodology and in data used for measurement. 
Table 8. Regional poverty 2009

\begin{tabular}{llllll}
\hline & $\begin{array}{l}\text { Rural } \\
\mathbf{( \% )}\end{array}$ & $\begin{array}{l}\text { Urban } \\
\mathbf{( \% )}\end{array}$ & $\begin{array}{l}\text { Total } \\
\mathbf{( \% )}\end{array}$ & $\begin{array}{l}\text { Per capita } \\
\text { income: } \\
\text { Rural }\end{array}$ & $\begin{array}{l}\text { Per capita } \\
\text { income: }\end{array}$ \\
\hline Sumatra & 15.0 & 12.2 & 13.9 & 357 & 558 \\
Java-Bali & 17.7 & 10.6 & 13.7 & 294 & 543 \\
Nusa Tenggara & 22.4 & 24.6 & 23.0 & 253 & 405 \\
Kalimantan & 9.1 & 5.1 & 7.5 & 376 & 570 \\
Sulawesi & 18.3 & 6.7 & 14.8 & 313 & 591 \\
Maluku & 25.9 & 7.5 & 20.9 & 315 & 707 \\
Papua & 46.3 & 5.9 & 37.1 & 311 & 550 \\
Indonesia & 18.9 & 10.7 & 14.1 & & 570 \\
\hline
\end{tabular}

Source: BPS (2010), Resosudarmo and Yusuf (2009).

Note: Per capita income in $R p^{\prime} 000$ (2008 prices).

number is both surprising and worrying, for it implies that there are too many Indonesian people on the brink of official poverty. Suryahadi et al. (2011) confirm this. They found that 47 percent of the poor in 2008 stayed poor in 2009, and 53 percent graduated to near-poor and non-poor. But 49 percent of the poor in 2009 were not poor in 2008.

Second, non-income poverty is a more serious problem than income poverty. This includes high malnutrition rates, poor maternal health, weak education outcomes, and low access to safe and clean water and sanitation. All the non-income poverty measures, except unhygienic floor (e.g., soil floor), ${ }^{3}$ are worse than monetary poverty (Suryahadi et al. 2011). Furthermore, such non-income poverty is more prevalent in rural areas.

Third, regional disparities in poverty in Indonesia are considerable. The poverty incidence is far higher in eastern Indonesia, but most of the poor live in western Indonesia. For example, the 2009 poverty rate in Java/Bali was 13.7 percent (down from 15.7 percent in 2004) whereas the rate in the remote Papua was 37.1 percent (down from 38.7 percent in 2004). But Java/Bali is home to 57 percent of Indonesia's poor, and Papua has only 3 percent (Table 8 ).

The persistence of poverty is partly related to the structural change of the Indonesian economy. Roughly 62 percent of Indonesian poor people are engaged in agriculture (in its broad definition, including livestock, forestry, and fishery), which is less productive compared with the others. Many peasants do not have land or they own insufficient land to earn a living. Some peasants therefore shift to other jobs in

3 "Soil floor" is the original phrase used by the cited authors. It refers to a house floor that is far below today's standard average house in urban areas. For example, the floor is actually hardened soil. 
Figure 2. Unemployment

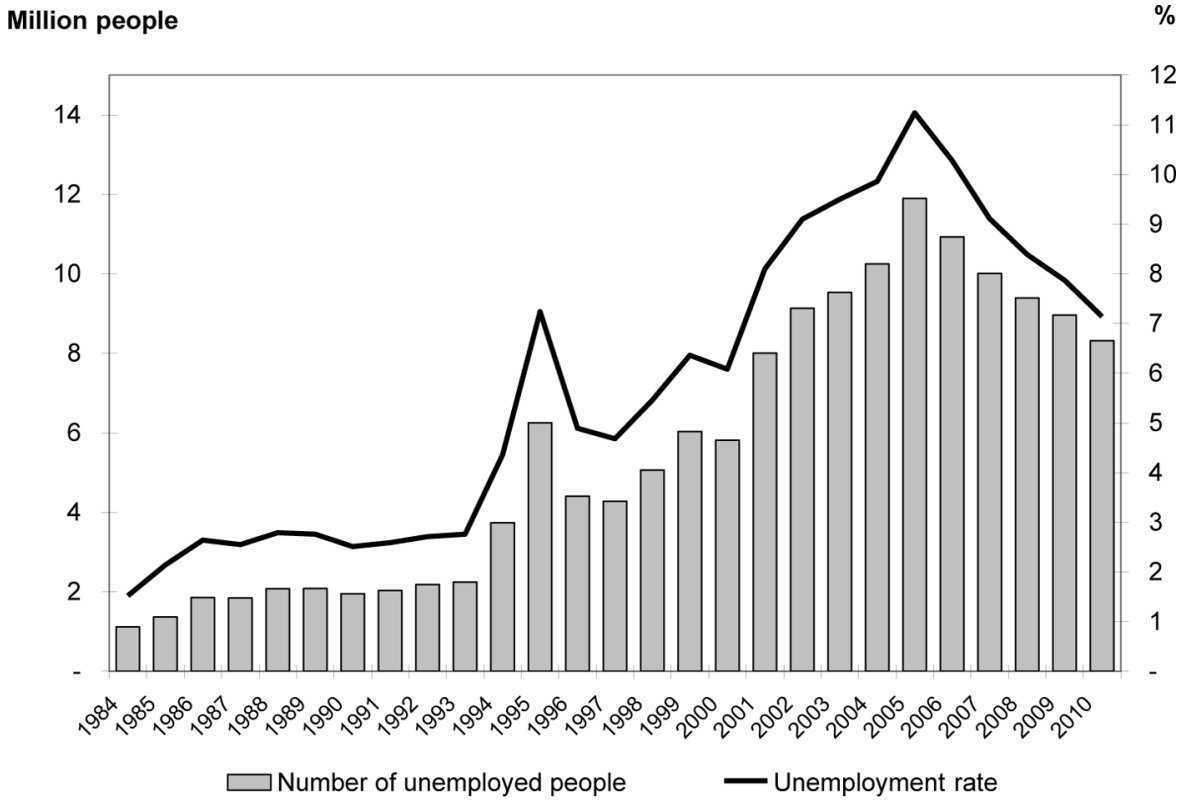

Source: Compiled from CEIC database.

search of a better living. With a low level of education and/or skills, some of them fail to meet job requirements and finally wind up being unemployed.

The unemployment rate has remained high for a long period (Figure 2). Since the AFC, the unemployment rate has increased significantly and it has been slow to reverse. The current unemployment rate is around 7 percent, which is far higher than that in the 1980s. Tarsidin (2009) decomposes unemployment into structural and cyclical unemployment and finds that Indonesia is currently experiencing structural unemployment generated by the structural change of the Indonesian economy. Industries have become more capital-intensive and hence require better and higher education and/or skills. Therefore the re-allocation of labor from agriculture to industry is constrained.

The dichotomy of rural and urban economy is also responsible for poverty and income inequality in Indonesia. The rural economy, characterized with agricultural activities, does not have a tight linkage with the urban economy. Farmers are merely sellers of agricultural crops and consumers of manufactured goods from the urban 
economy. For some who are engaged in non-agricultural activities, it is only on a small scale and serves a narrow market. The urban economy does not adequately leverage the income generating capacity of people living in rural areas. This implies that the urban economy's support to enhance economic growth in rural areas is limited. Suselo and Tarsidin (2008a) show that where people live also determines their poverty status. In 2004, by living in an urban area, the probability of a household not becoming poor would increase 4.01 percent compared to if they had lived in a rural area. In 2007 this probability increased to 16.80 percent.

Suselo and Tarsidin (2008b) show that the agriculture sector is the highest contributor of poverty in almost all regions. It is also the most responsive sector, with its high growth elasticity of poverty reduction - that is, every 1 percent growth of the sector could reduce 2.97 percent of the HCR. As a comparison, 1 percent growth in the manufacturing sector can reduce 0.11 percent of the HCR.

Many programs have been launched to reduce poverty, such as direct cash transfer, conditional cash transfer (both at household and at community level), and programs to provide cheap education, health services, clean water, and micro-financing. Although the programs contribute to an overall policy to reduce poverty, most of them are ad hoc and short-term in nature. For people living in a rural area (most of them are involved in the agricultural sector) low productivity and low added value of their output are the main problems. As for those living in an urban area, the problem is finding a job with little or no education or expertise. The challenge in a longer-term perspective is therefore to have a well-functioning social protection program. This is important not just for poverty eradication but it is also needed as a complement to making the otherwise rigid labor market more flexible.

\section{The supply constraints: logistics and infrastructure ${ }^{4}$}

Basri and Patunru (2008) argue that the constraints on economic growth in Indonesia lie more in the supply side rather than in the demand side. Indonesia is a beneficiary of the expansion of the production networks that is occurring in East Asia; and, in order to take full advantage of these production networks, Indonesia has to improve its investment climate and to relax "supply constraints." The two most important supply constraints are the logistics system and the infrastructure system. The logistics system includes input logistics (non-production-related costs

4 Part of this section borrows from Patunru's address to the workshop on "Improving Supply Chain Connectivity Across APEC Economies Through Open and Competitive Services," Manila, 22-24 September 2010, and Hanoi, 27-29 September 2010. 
of acquiring raw material and capital goods [e.g., the cost of transporting inputs from factor market to the production plant]), in-house logistics (e.g., inventory system, labor management), and output logistics (costs incurred while transporting goods to the final markets). The infrastructure system refers to hard infrastructure (e.g., roads, ports, bridges) and soft infrastructure (the management of roads, ports, bridges, etc.). These two constraints have made transportation of goods very costly (e.g., Indonesia's trucking costs are the highest in ASEAN). The country has failed to capitalize on its unique archipelagic geography by not having a primary international hub port, by not having adequate capacity at its domestic ports, and by not managing the domestic ports efficiently.

\section{I Indonesia in the midst of regional economic integration}

Fung, Iizaka, and Siu (2010) have documented the integration process of East Asia masterfully. The shares of East Asian imports and exports that are absorbed within the region have increased from 23 percent and 26 percent, respectively, in 1985 to 45 percent and 41 percent, respectively, in 2006. In contrast, the shares of East Asia imports from North America and EU-15 have dropped from 17 percent and 14 percent, respectively, in 1985 to 10 percent and 10 percent, respectively, in 2006. The share of East Asian exports to North America has decreased from 29 percent to 18 percent and the share of East Asian exports to EU-15 has increased a little bit from 11 percent to 14 percent. Of particular interest is the role of China. East Asia's import share from China increased from a mere 6 percent in 1985 to 16 percent in 2006, and the export share to China has increased from 5 percent to 13 percent. On the other hand, East Asia's import share from Japan has dropped from 26 percent to 14 percent and export from 17 percent to 9 percent. Clearly, there has been a big switch away from East Asia's reliance on the North American markets toward itself and from Japan to China.

Indonesia's trade pattern has followed the same general trends in East Asia. Indonesian import from and export to East Asia increased markedly from 17 percent and 18 percent to 46 percent and 37 percent from 1985 to 2006 (see Table 9). Corresponding figures with respect to North America are 19 percent and 22 percent to 17 percent and 19 percent. Indonesia's trade with China is also increasing ( 2 percent and 0.5 percent to 7 percent and 10 percent) while trade with Japan is decreasing (26 percent and 46 percent to 14 percent and 17 percent), even though in absolute terms the latter still dominates (not shown).

We now present two types of evidence to suggest that Indonesia is not participating adequately in the expansion of the production networks. The first type of evidence is to compare the degree that Indonesia trades with the rest of East Asia compared 
Table 9. Southeast Asian integration (shares of import and export, in percent)

\begin{tabular}{|c|c|c|c|c|c|c|}
\hline Countries & Year & East Asia & NIEs & ASEAN4 & N. America & EU15 \\
\hline Singapore & $\begin{array}{l}1985 \\
1995 \\
2003 \\
2006\end{array}$ & \begin{tabular}{l|l}
32.6 & 31.4 \\
36.5 & 44.2 \\
46.8 & 53.4 \\
49.2 & 54.7
\end{tabular} & \begin{tabular}{r|r}
6.8 & 9.3 \\
11.8 & 15.4 \\
10.7 & 17.1 \\
12.5 & 16.7
\end{tabular} & \begin{tabular}{l|l}
17.2 & 20.6 \\
21.5 & 26.5 \\
28.0 & 30.0 \\
25.3 & 28.2
\end{tabular} & \begin{tabular}{l|l}
15.5 & 21.9 \\
15.5 & 18.8 \\
13.6 & 13.1 \\
13.1 & 10.5
\end{tabular} & \begin{tabular}{l|l}
12.2 & 11.0 \\
13.4 & 13.4 \\
11.7 & 12.1 \\
10.9 & 10.6
\end{tabular} \\
\hline Thailand & $\begin{array}{l}1985 \\
1995 \\
2003 \\
2006\end{array}$ & \begin{tabular}{l|l}
23.4 & 25.6 \\
24.7 & 30.9 \\
33.4 & 34.7 \\
36.3 & 35.3
\end{tabular} & \begin{tabular}{l|l}
13.7 & 15.4 \\
15.3 & 23.0 \\
13.8 & 17.9 \\
13.6 & 16.6
\end{tabular} & \begin{tabular}{r|l}
7.2 & 6.3 \\
6.4 & 4.9 \\
11.6 & 9.7 \\
12.1 & 9.6
\end{tabular} & \begin{tabular}{r|l}
12.6 & 20.9 \\
12.7 & 18.9 \\
10.0 & 18.2 \\
7.1 & 16.0
\end{tabular} & \begin{tabular}{r|l}
16.1 & 19.8 \\
15.9 & 15.1 \\
10.0 & 14.7 \\
8.4 & 13.0
\end{tabular} \\
\hline Malaysia & $\begin{array}{l}1985 \\
1995 \\
2003 \\
2006\end{array}$ & \begin{tabular}{l|l}
31.0 & 36.4 \\
31.0 & 40.4 \\
45.9 & 43.0 \\
49.7 & 43.1
\end{tabular} & \begin{tabular}{l|l}
22.4 & 29.1 \\
23.7 & 31.6 \\
25.1 & 28.7 \\
25.2 & 26.7
\end{tabular} & \begin{tabular}{r|l}
6.6 & 6.3 \\
5.0 & 6.2 \\
12.0 & 7.8 \\
12.5 & 9.2
\end{tabular} & \begin{tabular}{l|l}
16.4 & 13.7 \\
17.1 & 21.5 \\
16.0 & 20.2 \\
13.0 & 19.4
\end{tabular} & \begin{tabular}{l|l}
16.1 & 14.9 \\
15.6 & 14.2 \\
11.8 & 12.1 \\
11.1 & 12.1
\end{tabular} \\
\hline Philippines & $\begin{array}{l}1985 \\
1995 \\
2003 \\
2006\end{array}$ & \begin{tabular}{l|l}
30.6 & 20.6 \\
29.2 & 24.6 \\
35.5 & 42.4 \\
43.4 & 41.3
\end{tabular} & \begin{tabular}{l|l}
13.7 & 12.9 \\
21.0 & 16.2 \\
20.8 & 21.5 \\
23.9 & 20.9
\end{tabular} & \begin{tabular}{r|l}
11.5 & 6.1 \\
5.9 & 7.2 \\
10.2 & 7.7 \\
11.3 & 8.2
\end{tabular} & \begin{tabular}{r|l}
25.9 & 37.5 \\
19.9 & 37.4 \\
9.3 & 12.7 \\
7.8 & 11.7
\end{tabular} & \begin{tabular}{r|l}
9.3 & 16.2 \\
10.7 & 16.9 \\
10.9 & 13.1 \\
9.7 & 11.5
\end{tabular} \\
\hline Indonesia & $\begin{array}{l}1985 \\
1995 \\
2003 \\
2006\end{array}$ & \begin{tabular}{l|l}
17.2 & 18.4 \\
24.6 & 31.0 \\
40.1 & 35.4 \\
46.0 & 37.3
\end{tabular} & \begin{tabular}{l|l}
13.5 & 16.1 \\
17.0 & 22.2 \\
21.5 & 25.5 \\
26.2 & 22.4
\end{tabular} & \begin{tabular}{r|r}
1.2 & 1.9 \\
3.9 & 5.0 \\
9.4 & 11.0 \\
10.0 & 9.1
\end{tabular} & \begin{tabular}{l|l}
18.7 & 22.0 \\
13.7 & 14.7 \\
22.4 & 21.0 \\
16.6 & 18.9
\end{tabular} & \begin{tabular}{r|l}
19.0 & 6.4 \\
20.1 & 14.9 \\
8.1 & 16.3 \\
8.3 & 18.0
\end{tabular} \\
\hline
\end{tabular}

Source: Fung, Iizaka, and Siu (2010).

Note: The first numbers indicate "import from" and the second "export to."

with the neighboring ASEAN countries of Thailand, Malaysia, the Philippines, and Singapore. The share of national exports going to East Asia in 2006 is 37 percent for Indonesia, 35 percent for Thailand, 43 percent for Malaysia, 53 percent for Singapore, and 41 percent for the Philippines (see Table 9). As the Indonesian share is higher than that of only Thailand, it is likely that Indonesia is lagging behind other ASEAN countries in joining the production networks.

The second type of evidence that Indonesia is lagging in its participation in production networks is obtained from the comparison between the growth rate of total trade and the growth rate of trade in parts and components. When the expansion of trade is driven by the expansion of trade in parts and components, then the growth rate of the former is lower than the growth rate of the latter. According to Fung et al. (2010), the average growth rate of imports of intermediate goods in Asian nations in 1998-2007 was 14 percent and that of final goods was 10 percent. The corresponding growth rates for exports were 13 percent for intermediate goods and 12 percent for final goods. For the world as a whole, the growth rate for imports was 10 percent for intermediate goods and 9 percent for final goods; and the growth rate for export was 10 percent for intermediate goods and 9.5 percent for final goods. For Indonesia, however, the average growth rate of import was 12 percent for final goods and 10 percent for intermediate goods; and the average growth rate of export was 9 percent for final goods and 13 percent for intermediate goods. So, although on the ex- 
Table 10. Disconnected markets of Indonesia (prices in IDR)

\begin{tabular}{lcccccc}
\hline & Rice & Wheat flour & Sugar & Cooking oil & Salt & Cement \\
\hline E. Jawa & 4,250 & 3,800 & 6,000 & 4,450 & 1,600 & 38,000 \\
W. Kalimantan & 4,400 & 4,000 & 5,800 & 4,500 & 2,400 & 37,500 \\
E. Kalimantan & 4,500 & 4,000 & 6,500 & 4,500 & 2,000 & 30,000 \\
S. Sulawesi & 4,400 & 3,500 & 5,800 & 4,500 & 2,000 & 30,500 \\
E. NusaTenggara & 4,200 & 4,500 & 7,000 & 6,300 & 2,000 & 31,000 \\
Merauke & 5,000 & 7,000 & 7,000 & 6,670 & 3,000 & 62,000 \\
Nabire & 6,000 & 10,000 & 11,000 & 11,000 & 4,000 & 23,000 \\
Paniai & 10,000 & 7,500 & 8,000 & 7,000 & 8,000 & 60,000 \\
\hline
\end{tabular}

Source: Basri (2010).

port side Indonesia has been following the trend (i.e., export of intermediate goods grew higher than that of final goods), the import side showed the opposite.

\subsection{The sources of non-competitiveness}

In our opinion, the most important reason for Indonesia's inadequate participation in the expansion of production networks in East Asia is the backwardness of the logistic system and the infrastructure system in Indonesia. One symptom of the backwardness of the two systems is the absence of domestic connectivity, as evidenced by the stark differences in prices for basic commodities across space. Table 10 reports that the price of medium rice was around Rp 4,000 in Java, Kalimantan, Sulawesi, and Nusa Tenggara but was Rp 10,000 in remote Paniai (in Papua).

According to the World Economic Forum (2009), Indonesia ranked 54 out of 134 countries in terms of competitiveness. Indonesia is less competitive than Thailand, Malaysia, Singapore, and China, and more competitive than Vietnam and the Philippines. The top culprits for Indonesia's low competitiveness rank are inefficient government bureaucracy and an inadequate supply of infrastructure. In terms of logistic performance, Indonesia is the worst in ASEAN. Its Logistic Performance Index rank in 2010 is 75-that is, behind Singapore (2), Malaysia (29), Thailand (35), the Philippines (44), and Vietnam (53). Indonesia also lags behind its neighbors in customs, infrastructure, and international shipments. According to the World Bank (2008), the processing time needed for export in Indonesia is 21 days, compared with 9.8 days in the OECD, even though the numbers of documents needed are roughly the same.

Table 11 reports that the ranking of overall infrastructure in Indonesia slipped significantly in 2009, dropping from being 46 in 2008 to 96 in 2009. This fall in ranking occurred despite improvements in many dimensions (e.g., in 2008, Indonesia ranked 105 for roads and 104 for ports, and in 2009 it ranked 94 and 95). 
Table 11. Rankings of infrastructure quality (2008: 134 countries; 2009: 133 countries)

\begin{tabular}{|c|c|c|c|c|c|c|c|c|c|c|}
\hline & \multirow{2}{*}{\multicolumn{2}{|c|}{ Indonesia }} & \multicolumn{4}{|l|}{ The } & \multirow{2}{*}{\multicolumn{2}{|c|}{ Vietnam }} & \multirow{2}{*}{\multicolumn{2}{|c|}{ China }} \\
\hline & & & Phili & pines & Mala & & & & & \\
\hline & 2008 & 2009 & 2008 & 2009 & 2008 & 2009 & 2008 & 2009 & 2008 & 2009 \\
\hline Quality of infrastructure (overall) & 46 & 96 & 94 & 98 & 19 & 27 & 97 & 111 & 58 & 66 \\
\hline Quality of roads & 105 & 94 & 94 & 104 & 17 & 24 & 102 & 102 & 51 & 50 \\
\hline Quality of railroad infrastructure & 58 & 60 & 85 & 92 & 17 & 19 & 66 & 58 & 28 & 27 \\
\hline Quality of port infrastructure & 104 & 95 & 100 & 112 & 16 & 19 & 112 & 99 & 54 & 61 \\
\hline Quality of airport infrastructure & 75 & 68 & 89 & 100 & 20 & 27 & 92 & 84 & 74 & 80 \\
\hline Quality of electricity infrastructure & 82 & 96 & 82 & 87 & 71 & 39 & 104 & 103 & 68 & 61 \\
\hline Telephone lines & 100 & 79 & 105 & 103 & 31 & 72 & 37 & 36 & 47 & 49 \\
\hline
\end{tabular}

Source: World Economic Forum (2009).

In a study on land transportation costs, the Institute for Economic and Social Research (LPEM-FEUI 2008) found that trucking costs in Indonesia (a number of provinces in Sulawesi, Java, and Sumatra were sampled) could reach as high as USD 0.34 per kilometer. This is higher than the average trucking cost in ASEAN, USD 0.22 per kilometer (Carana Corporation 2004). One would reasonably guess that for an archipelagic country like Indonesia, river and sea transportation would be cheaper. This proved not to be true because LPEM-FEUI (2010) found that the cost could reach even higher at USD 0.50 per kilometer. The Indonesian archipelago is passed by world shipping lines. Nevertheless, thus far there is no primary international hub port. Patunru, Nurridzki, and Rivayani (2009) posited that difficult topography as well as bad management caused this. For example, in Semarang (Central Java), dredging and widening the port is not possible because of the topographical nature of the location (sandy, etc.), and the existing port management company, the stateowned Indonesian Port Corporation, has no incentives to improve its performance.

An interesting study by De (2009) reveals that most Indonesian ports impose quite a significant amount of "auxiliary charges" in addition to base charges. Such auxiliary charges include container handling charges and government duties (base charges refer to fares set by shipping lines). The auxiliary charges in Indonesian ports can take up more than 40 percent of the total freight costs. For example, it costs USD 841 to send goods from Indonesia to China in a 20-foot container, and 43 percent of the cost is auxiliary charges. On the other hand, shipping goods from China to Indonesia costs USD 500, again with 43 percent going to auxiliary charges.

Another study, LPEM-FEUI (2005), found that the total logistic costs were around 14 percent of the production costs in Indonesia, compared with less than 5 percent in Japan. The study broke down the logistic costs into input logistics (from raw material and capital good vendor to processing plant), in-house logistics (within the firm itself), and output logistics (from firm to the marketplace). It was found that 
both input and output logistics are the main contributors, accounting for 7 percent and 4 percent, respectively, of production costs. This implies that the bulk of logistic costs are beyond the firm's control (e.g., lack of road and port capacity, illegal collection, and retribution on the street). LPEM-FEUI (2009) found that informal payments could vary from rupiah 23,000 (for imported goods that go through the "green lane" - less hurdled line) to rupiah 1.5 million (in the "red lane" - more inspected). This all suggests that improvement of the logistics services in ports should not focus only on the hard infrastructure but also on the soft infrastructure (the management) as well. ${ }^{5}$

Not surprisingly, transportation has been identified as the second most severe obstacle to economic growth after macroeconomic instability (LPEM-FEUI 2008). Transportation issues are even more important than labor and tax issues.

\section{Final remarks}

Hal Hill $(1996,251)$ conjectured that Indonesia's slow growth during the post-1988 East Asian boom was the result of "serious supply-side bottleneck" (Hill 1996, 251). This paper has argued that this situation of supply constraints is even more important today. The logistics system and the infrastructure system must be improved rapidly and comprehensively if Indonesia is to realize its growth potential.

This paper has been rather silent on politics and participation in international economic governance. Indonesia's politics are more stable now than in the past, although adjustments to various drastic reforms (e.g., regional decentralization of economic and political governance) are still in progress. Indonesia has become increasingly active in international forums such as ASEAN, APEC, and G20. All these are in parallel with the country's involvement in the regional economic production networks. Indonesia has started to embrace the opportunity of international market access. ${ }^{6}$

Indonesia's export and import structure will keep transforming as the country increasingly engages in the regional and global production networks. This engagement requires better preparation by the Indonesian government.

5 Additional payments are perceived to be the main obstacle in ship clearance. Patunru, Nurridzki, and Rivayani (2009) noted that 75 percent of respondents reported additional payments from vessel arrival until leaving the port as being a severe obstacle. Around 55 percent complained about the port infrastructure. In the case of cargo clearance, 84 percent of respondents said that additional payment inside the port has been a major obstacle.

6 On a recent political development, see, for example, Patunru and von Luebke (2010). 


\section{References}

ADB (Asian Development Bank). 2010. Key Indicators for Asia and the Pacific 2010. Manaluyong City, Philippines: ADB.

Ashcroft, Vincent, and David Cavanough. 2008. Survey of Recent Developments. Bulletin of Indonesian Economic Studies 44(3):335-363.

Basri, M. Chatib. 2010. Navigating Beyond Recovery: Growth Strategy for an Archipelagic Country, The Case of Indonesia. Presentation at the workshop on Strategies for Asia's Sustainable Growth beyond the Global Crisis: Infrastructure, the Environment, and the Finance, organized by the Institute for Economic and Social Research (LPEM-FEUI) and Japan Bank for International Cooperation (JBIC), 15 February, Jakarta.

Basri, M. Chatib, and Arianto A. Patunru. 2008. Indonesia's Supply Constraints. A background paper commissioned by the OECD for preparation of Indonesia's Economic Assessment." OECD Economic Surveys 17 (July).

BPS (Statistics Indonesia). 2010. Statistical Yearbook of Indonesia. Jakarta: BPS.

Brodjonegoro, Bambang. 2004. The Effects of Decentralization on Business in Indonesia. In: Business in Indonesia: New Challenges, Old Problems, edited by M. Chatib Basri and Pierre van der Eng, pp. 125-140. Singapore: Institute for Southeast Asian Studies.

Carana Corporation. 2004. Impact of Transport and Logistics on Indonesia's Trade Competitiveness. Arlington, VA: Carana Corp.

De, Prabir. 2009. Empirical Estimates of Transportation Costs: Option for Enhancing Asia's Trade. In: Infrastructure's Role in Lowering Asia's Trade Costs: Building for Trade, edited by Douglas H. Brooks and David Hummels, pp. 73-112. Cheltenham: Asian Development Bank Institute and Edward Elgar.

Fung, Kwok-Chiu, Hitomi lizaka, and Alan Siu. 2010. United States, Japanese, and Korean FDI and Intra-East Asian Trade. Asian Economic Papers 9:129-154.

GOI (Government of Indonesia). Various years. State Budget (RAPBN/APBN). Jakarta: Ministry of Finance.

Higgins, Benjamin. 1968. Economics Development: Problems, Principles, and Policies. Revised edition. New York: WW Norton and Co.

Hill, Hal. 1996. The Indonesian Economy Since 1966: Southeast Asia's Emerging Giant. Cambridge: Cambridge University Press.

Hill, Hal. 2000. The Indonesian Economy. Second edition. Cambridge: Cambridge University Press.

IMF (International Monetary Fund). 2010. World Economic Outlook 2010. Washington, DC: IMF.

LPEM-FEUI (Institute for Economic and Social Research, University of Indonesia). 2005.

Inefficiency in the Logistics of Export Industries: The Case of Indonesia. Report in collaboration with Japan Bank for International Cooperation (JBIC), Jakarta. Jakarta: LPEM-FEUI.

LPEM-FEUI (Institute for Economic and Social Research, University of Indonesia). 2008. Domestic Trade Barrier: The Case of Transportation Costs in Indonesia. Report in collaboration with The World Bank and The Asia Foundation. Jakarta: LPEM-FEUI. 
LPEM-FEUI (Institute for Economic and Social Research, University of Indonesia). 2009. Time of Release: A Study of Bottlenecks in Ports and Customs Clearance at Jakarta's Tanjung Priok Port. Report in collaboration with The World Bank. Jakarta: LPEM-FEUI.

LPEM-FEUI (Institute for Economic and Social Research, University of Indonesia). 2010. Goods Transportation in East Nusatenggara, Indonesia. Report in collaboration with The Asia Foundation. Jakarta: LPEM-FEUI.

McLeod, Ross H. 2011. Survey of Recent Developments. Bulletin of Indonesian Economic Studies 47(1):7-34.

Patunru, Arianto A. 2010. Political Economy of Environmental Protection in Indonesia. Paper presented at "The Environments of the Poor in the Context of Climate Change and the Green Economy: Making Sustainable Development More Inclusive" conference organized by the Asian Development Bank (ADB), 24-26 November, New Delhi, India.

Patunru, Arianto A., Nanda Nurridzki, and Rivayani. 2009. Port Competitiveness in Indonesia: A Case Study of Semarang and Surabaya. In: Infrastructure's Role in Lowering Asia's Trade Costs: Building for Trade, edited by Douglas H. Brooks and David Hummels, pp. 113-147.

Cheltenham: Asian Development Bank Institute and Edward Elgar.

Patunru, Arianto A., and Christian von Luebke. 2010. Survey of Recent Developments. Bulletin of Indonesian Economic Studies 46(1):7-31.

Resosudarmo, Budy P., and Arief A. Yusuf. 2009. Survey of Recent Developments. Bulletin of Indonesian Economic Studies 45(3): 287-315.

Suryahadi, Asep, Umbu R. Raya, Deswanto Marbun, and Athia Yumna. 2011. Accelerating Poverty and Vulnerability Reduction: Trends, Opportunities, and Constraints. In: Employment, Living Standards and Poverty in Contemporary Indonesia, edited by C. Manning and S. Sumarto, pp. 68-89. Singapore: Institute of Southeast Asian Studies.

Suselo, Sri L., and Tarsidin. 2008a. The Persistence of Poverty in Indonesia [in Bahasa Indonesia]. Bank Indonesia-Working Paper (unpublished). Jakarta: Bank Indonesia.

Suselo, Sri L., and Tarsidin. 2008b. Poverty in Indonesia: The Impact of Economic Growth and Structural Change [in Bahasa Indonesia]. Buletin Ekonomi Moneter dan Perbankan 11(2):155-194.

Tarsidin. 2009. Structural Unemployment: Its Affecting Factors and Dynamics [in Bahasa Indonesia]. Buletin Ekonomi Moneter dan Perbankan 11(3): 201-231.

Thee, Kian Wie, and Siwage D. Negara. 2010. Survey of Recent Developments. Bulletin of Indonesian Economic Studies 46(3):279-308.

World Bank. 1993. The East Asian Miracle: Economic Growth and Public Policy. Washington, DC: World Bank.

World Bank. 2006. Making the New Indonesia Work for the Poor. Jakarta: The World Bank Office.

World Bank. 2008. Doing Business 2008. Washington, DC: World Bank.

World Economic Forum. 2009. Global Competitiveness Report 2009-10. Geneva: World Economic Forum. 